\title{
Nativization of English Language in a Multilingual Setting: The Example of Nigeria
}

\section{Bola Margaret Tunde-Awe Ph.D}

\author{
Arts Education Department, Adekunle Ajasin University \\ Akungba-Akoko, Ondo State, Nigeria \\ bolajokotundeawe@gmail.com
}

\section{Doi:10.5901/ajis.2014.v3n6p485}

\begin{abstract}
This paper discusses the history of the English language in Nigeria, its international status and its numerous functions. The author maintains that the English language has adapted itself to the different exigencies, particularly the linguistic and cultural contexts of its use. The author gives features and nuances of the English that are peculiar to the Nigerian users to show the nativization of the English language in Nigeria. She opines that the English language has continued to exist in a multilingual setting like Nigeria where an indigenous national language has not evolved. The author discusses some scholarly criteria for the standardization of the world Englishes, which she maintains, must be respected. She also reinforces that Nigerian English is a variety of the world Englishes. She concludes that any discussion of nativization or domestication must not, in any way, jettison social acceptability and intelligibility so that Nigerian English will enjoy a wide and social use.
\end{abstract}

Keywords: English language, World Englishes, Nigerian English, nativization, standardization, social acceptability and intelligibility

\section{Introduction}

Communication maintains and animates life. The essence of communication is largely dependent on the existence of language. Adeyanju (2002) and Babatunde (200) perceive language as such a divine benevolence to man that it has become so inexorably tied to the effective existence of man in the society that any meaningful discussion of man must begin with language and end with it. Language is undoubtedly an instrument which gives vivid and clear expression to human thought.

Nativization is a term used when people take up the citizenship of another country where they are domiciled. Nativization is a term commonly adapted by sociolinguists for describing the indigenization of English in a second language environment. According to Schneider (2007), post colonial varieties of English (New Englishes) follow through some basic developmental path, slowly establishing their own identities through a series of stages till they become independent varieties in their own right. Five stages in the developmental cycle were identified by Schneider (2007:56). These are: foundation, exonormative stabilization, nativization, endonormative, and differentiation. The third stage is directly related to our discussion in this paper. By the term nativization, bilingual and multilingual speakers create a new local variety of English which is influenced by the linguistic systems and cultural norms of the speakers' first languages. During this stage, the new variety is usually considered deficient, so norms are still provided by the colonial variety, especially in the classroom.

As noted by Grieve (1964) cited by Hunjo (2002) and Adedimeji (2007), English language has assumed a function that relates to the expression of ideas typically African. The language is a vehicle of African cultures as well as of English and in these cultures (African), concepts exist which do not exist in English culture. So, if English is to be an effective mode of communication in Africa, it is essential that it adapts itself so as to be able to express these concepts. Odumuh (1984) also aptly expresses Achebe (1974) when he describes Nigerian English as a variety belonging to Nigeria but still in communion with its ancestral home, altered to suit its new African surrounding. So, the use of English in Nigeria is characterized by the idiosyncratic norms reminiscent of the Nigerian linguistic ecology and indeed her cultural heritage. On the justification for the presence of these linguistic features in Nigerian English and other non-native speakers, Soyinka (1988:126) maintains that:

... when we borrow an alien language to sculpt or paint in, we must begin by co-opting the entire properties in our matrix of thought and expression. We must stress such a language, stretch it, impact and compact it, fragment and reassemble it with no apology, as required to bear the burden of experiencing and of experiences, be such experiences formulated or not in the conceptual idioms of the language 
It is this adaptation of the English language to the Nigerian environment that is responsible for the phenomenon of pragmatic nativization (Bamgbose, 1995, and Hunjo, 2002).

Most previous scholars have established the existence of World Englishes (WE) and its global recognition. Also the phenomenon of Nigerian English and the exigency for its adoption as a second language and its nativization process have been dealt with. This paper is a reappraisal meant to strengthen those existing literature. This becomes necessary because Nigerian English is still in its developmental stage and till date, no successful effort has been made to standardize and codify it. Also, the nagging problem of effective communication in Nigeria has not been addressed by the government. Therefore, this paper reappraises Nigerian English with a viewing to identifying new linguistic items in emerging Nigerian English. It also reviews the parameters adjudged suitable for measuring standards in World Englishes. Some representative linguistic features that typify Nigerian English (at the phonological, morphological, syntactic, and semantic levels) have been adopted from previous scholars like Jowitt (1991:88-106) and Alabi (2003:176-196) and Kirkpatrick and Deterding (2011:373-387). The adopted corpora which were strewed with the new entrants were obtained experientially-through personal observation of people's way of expression.

\section{History of the English Language in Nigeria}

An examination of the history of English language in Nigeria is crucial to the examination of the roles the language has performed since its inception on the Nigerian soils. Babatunde (2001) reminds us of the unprecedented incident of the exportation of the English language to all the corners of the world by its original users for either geopolitical or socioeconomic reasons. Nigeria is one of such places the English man planted the seed of this immortal kernel of communication.

Nigeria's first contact with English language was believed to be some period before the trans-Atlantic slave trade (Alabi, 2003). It was reported that as from 1553, the English men paid very brief visits to the Nigerian coasts, especially the ports of Benin and old Calabar and the type of communication which evolved between the English men and Nigerians, was an English-based pidgin. Later when slave trafficking increased, tremendously in the 18th century, with England as a major exporter of slaves, African traders saw more need to learn the European languages. Therefore, a few of the sons of these traders were sent to England to learn English, among other things. On their return, they established schools in old Calabar to teach the rudiments of English (Babatunde, 2001 and Alabi, 2003).

When slave trade was abolished, there was the need to find an economic alternative. Therefore, the explorers began to penetrate into Nigeria, beyond its coasts. Then the missionaries followed. They preached the gospel and promoted legitimate trade. They also built schools and introduced formal education which brought about the spread of English especially in Southern Nigeria. Some Nigerians were taught English primarily to help the missionaries in the Church and to make them serve as clerks, cooks, interpreters to the colonial administrators who came later to protect their trade and missionary activities. As Alabi further reveals, by 1903, the whole of Nigeria had come effectively under British rule. Government established its schools alongside those of the missionaries and through formal education, came the spread of English in Nigeria. In no time the language expanded to include media, business, worship, government and social functions. Consequently, the English language assumed (still assumes till date) the status of, not only a formidable second language, but also as an official language, a social symbol, and Nigeria's lingua franca (Jowitt, 1999 and Babatunde, 2001). As (Jolayemi, 2013) lately submits, on a global level, the English language is assigned the some crucial roles across the world and such, it has in fact, become the world's lingua franca.

\section{Linguistic Terrain in Nigeria}

Nigeria is believed to be one of the multi-lingual countries in Africa. Her linguistic diversity is considered an attribute. This fact of her diversity was recognized by the composers of Nigeria's first national anthem who agreed that tribe and tongue differences exist. Emenanjo (1990) states equivocally that Nigeria is a thoroughly multilingual country. As to the number and distinction between and among them, authors share slightly different opinions. Emenanjo quotes Handsford et al. (1976) which Emenanjo, thinks represents the best and most documentary compilation to have put the number of languages spoken in Nigeria at 394 entries - approximately, 400. Jowitt (1991) is convinced that it is a daunting task to attempt at determining the exact number of indigenous languages in Nigeria. He, however, puts his estimation to range from 200 to over 400.

A fundamental problem here is that of differentiating language from dialect (or how to classify a particular speech system that serves for communication within a social group) even as Hansford et al. (1976) quoted in Emenanjo (1990) 
believes that $90 \%$ of these languages are languages, not dialects. But then, would it be correct to say that Egba, ljebu, Ekiti, Okun and Owo speech systems are one language (Yoruba), several languages, or dialects? The assumption is that they are dialects.

In a situation like this, it would be discovered that some languages have greater prominence in national life than others. Ultimately, prominence and recognition are determined by the number of speakers and/or geographical spread. In the Nigerian situation, three of such distinct languages have been considered to stand out. These are: Hausa, Yoruba and Igbo each of which runs into several million speakers and as the Mother Tongue in at least four of the thirty six states in the Federation. Thus, the government has adopted the three as official languages for national purposes, especially in governance and education. These three languages are recommended, alongside the English language, for deliberations in the National Assembly and have been conspicuously mentioned in the National Policy on Education (FRN, 2007).

Adegbija's (1989) categorization of the language situation in Nigeria suffices to explain the multilingual and sociolinguistic state of Nigeria. His categorization of languages present in Nigeria is: the exoglossic language, the English imposed during colonization, the approximately 450 indigenous languages, of which Hausa, Yoruba and Igbo have been constitutionally recognized as main languages. Lastly, is Pidgin languages, the most predominant of which is the Nigerian Pidgin, resulting in at least initially from contact between Portuguese, English, and indigenous languages. It must be noted that within this environment, each linguistic community has some fairly united cultural practices that have their effects on the use of the English language in Nigeria.

\section{World Englishes and Criteria for Determining Standards}

The plurality and diffusion of English in the world is no longer in doubt: it is a reality and there are many models that represent the nature of Englishes around the world. Two of them are those of Kachru (1982) and McArthur (1998) tagged Three Circles of English and Circle of World Englishes respectively but the most influential model is Kachru's. His trichotomy of the English-Speaking World is widely used as the standard representation of the plurality of the English in the world. He used a circle analogy placing each country in one of three circles as follows (with examples added in italicized brackets):

The current sociolinguistic profile of English may be viewed in terms of three concentric circles...The Inner Circle refers to the traditional cultural and linguistic bases of English [e.g. Britain, USA, Australia). The Outer Circle represents the institutionalized non-native varieties (ESL) in the regions that have passed through extended periods of colonization [e.g. Singapore, India, Nigeria, Ghana). The Expanding Circle includes the regions where the performance varieties of the language are used essentially in EFL contexts [e.g. China, Japan, and Egypt] (Kachru 1992c:356-7).

In Kachru's model, users of English in the Inner Circle are endo-normative; those in the Outer circle are normdeveloping, while those in the Expanding Circle are exo-normative. Nigeria belongs to the outer circle and is therefore norm-developing. The process of norm-development is another transition for English space-wise. It relates to what is termed new Englishes, particularly those 'Englishes' that are characterized by contacts of English with the first language of its first and second language users. Second language users of English now adopt the language to express their culture, thoughts, and habits (Bamgbose, 1995, Hunjo, 2002 and Olatinwo, 2006). Consequently, a large stock of expressions non-native to their Inner Circle users of English now abound among the second language users in Nigeria, leading to the name 'Nigerian English'(or Nigerian English variant). This type of English is thought to be full of errors of usage at the level of phonology, morphology and syntax, lexis and semantics. Efforts have been made by different scholars to codify Nigerian English and as well distinguish between its standard and non-standard variety but controversies have trailed the efforts. Nonetheless, issues relating to criteria for determining standards are briefly discussed.

The opinions of scholars like Kachru (1982) and Kirkpatrick and Deterding (2011) are significant when discussing issues relating to standards. These scholars maintain that one fundamental principle of the study of World Englishes is that variation and change are natural and inevitable. Therefore, they submit that linguistic features which differ from Standard English are not necessarily errors but may instead represent components of new English. And as regards standards of world Englishes in general, Quirk (1982) for instance, maintains that the kind of English which unites all those who use the language should be the standard variety. On his part, Kachru (1982) argues that norms should be recognized by the people who use English in all speech communities and that native and non-native communities should work together in developing standards. His concern is mainly with the people in the Outer Circle and Englishes used only in the Inner and the Outer Circles (the varieties of English in the Expanding Circle are excluded). 
Kachru (1982) contests the traditional classification referred to as English as a Second Language (ESL) and English as a Foreign Language (EFL). He recognizes the development of many different varieties of English, so the language should not be seen in terms of a single monolithic standard. Instead, as there is a multitude of different Englishes, variation is the norm. And just as there are many varieties of British English, there are also many new Englishes which in turn have sub-varieties. So, for example, Indian English consists of a range of varieties, just as Nigerian English, Ghanaian English and so on. Kirkpatrick and Deterding (2011) point out that some scholars have criticized aspects of Kachru's (1982) model: it is historically and geographically based; it deals with countries rather than societies or individuals; and it fails to accommodate some places (such as Denmark, and Argentina) that seem to be moving from the Expanding-Circle to Outer-Circle status even though they have no colonial links with England or the United States. Furthermore, the model does not allow for the possibility of the increasing number of speakers with English as their first language in places such as Singapore and India. However, Bolton (2005:78) cited in Kirkpatrick and Deterding (2011.p.374) reveals that Kachru's Three Circles model was formulated in response to the single-standard orthodoxy of the time, and 'the strength of the World Englishes paradigm has lain and continues to lie in its consistent pluralism and inclusivity'.

\section{Varieties and Linguistic Features of World Englishes: Focus on Nigerian English}

Linguistic variation is a natural phenomenon and it is inevitable (Kirkpatrick and Deterding, 2011). The authors reveal that Inner Circle Englishes as well as New Englishes is characterized by variation, not just in pronunciation and vocabulary, but grammar as well. For example, historically, all Englishes had a rich set of present tense inflections on verbs. But now, the dialects of England generally have substantially reduced inflections and they are not the same in all varieties. In modern Standard English, for present tense verbs, there is only the -s ending for the third person singular. The dialect of East Anglia, however, generally has no present tense inflections at all, so 'he make them' and 'farmers make them' are grammatical in this variety (Kirkpatrick and Deterding, 2011:374). Furthermore, in the dialect of Scotland (several centuries back) the use of $-s$ is required on verbs with plural subjects unless the verb is adjacent to a pronoun (Ihalainen, 1994) also cited in Kirkpatrick and Deterding (2011:374). Following this rule, 'birds flies,' 'they fly' and 'they fly and swoops' are all grammatical. Variation in present tense marking is also seen in American dialects. Expressions such as 'folks sings' is grammatical in the English of the American South. If such variation abounds in the Inner Circle Englishes, it should not be surprising to find similar variation in new Englishes as well as EFL (Kirkpatrick and Deterding, 2011).

In Nigeria, the indigenous languages have had various influences on the use of English. Hence, the concept 'Nigerian English (NE)'. As revealed by Igboanusi (2002), the Standard English is spoken by just 20\% of Nigerians while Adegbija (2004) too reveals that only $20 \%$ of Nigerians are proficient in the language. This is a confirmation of the fact that there is a variety of the English language we can refer to as Nigerian English just as we have Ghanaian English, Australian English, American English, and so on. To this end, some features of Nigerian English as adopted from Jowitt (1991:90-92), Alabi (2003:186-191), Adedimeji (2007) and Kirkpatrick and Deterding, 2011) are examined at the levels of phonology, morphology and syntax, lexis and semantics.

\subsection{Phonological Features}

Some phonological features that occur in Nigeria English (NE) include avoidance of dental fricatives, reduction of final consonant clusters, and the use of syllable-based rhythm

(Alabi, 2003 and Kirkpatrick and Deterding, 2011).

a) Avoidance of dental fricatives: is a common feature of Nigerian English is the tendency to avoid using $|\theta|$ and $I \partial I$. For example, the initial $/ \theta /$ in words such as 'three' is often replaced with [t] by Yoruba speakers in South West Nigeria while Hausa speakers in the North use [s]. However, Kirkpatrick and Deterding (2011:378) reveal that the avoidance of fricatives also occur in other countries like Ghana, Singapore, Philippines and in some Inner-Circle Englishes. For example, in place of $/ \theta /$ many speakers in London use [f] while those in Ireland and also New York may use [t]. It is informative to reveal that the phenomenon is very much widespread in New Englishes and as the scholars submit, the absence of dental fricatives may become increasingly accepted in Standard English in the very near future.

b) Stress-based rather than syllable-based rhythm is often claimed to be the basis of of English speech timing in most Inner-Circle variety (Kirkpatrick and Deterding, 2011). Abercrombie (1967:97) emphasizes that all languages should be classified as either stress-timed or syllable timed. However, studies have revealed that 
people do not adhere to this view and Caudwell (2002) cited in Kirkpatrick and Deterding (2011:377) has questioned the fundamental rhythmic dichotomy. The use of syllable- based rhythm is common in new Englishes and Nigerian English is not an exception. For example, Singapore English, Philippines, India, Nigeria, and Jamaica are new varieties that have a syllable-based rhythm when compared to British English. However, British English too sometimes have variable rhythm. Crystal (1995a) states that syllable-based rhythm can be found in a range of speech styles such as baby talk, sarcastic utterances, many types of popular music, and some TV commercials. On this basis, Crystal (2003:171) speculates that this kind of rhythm might one day become the norm for all varieties of English.

Alabi (2003) reveals that in Nigerian English, syllable-timed instead of stress-timed rhythm is employed with a reduced system of intonation and there are often no differentiations between strong and weak stresses.

c) Misplacement of stress occurs in Nigerian English in lexical, phrasal, and clausal structures as shown in the following few examples culled from Jowitt (1991:90):

SE
FIREwood
MAdam
TEAspoon
conGRAtulate
inVEStigate
SITting-room
deVElopment fund
it SHOULD be

\author{
NE \\ fireWOOD \\ madam \\ teaspoon \\ congratulate \\ investiGATE \\ Sltting-room or sitting-ROOM \\ development FUND \\ it should BE
}

d) Pronunciation of some silent consonants in Nigerian English: in words such as honour, hour, heir, bomb comb, and climb, the underlined consonants are not phonetically realized in BE but Nigerian users of English include them.

\subsection{Morphology and Syntax}

At this level, some Nigerians can hardly differentiate mass and count nouns. Therefore some items which are not to be pluralized (mass nouns) are pluralized. For example: 'furnitures' instead of 'furniture', 'equipments' instead of 'equipment', 'informations' instead of 'information', 'luggages' instead of luggage', 'staffs' instead of 'staff'( Alabi, 2003).

a). Preposition is often misused. For example 'to' is dropped from certain non-finite verbs when they are required e.g. 'enable him do it' instead of 'enable him to do it', 'enable him go' instead of 'enable him to go', 'reply her letter' instead of 'reply to her letter'. 'voice out' instead of 'voice', 'advocate for' instead of 'advocate', 'congratulate for' instead of 'congratulate on', etc. b). Deviant usage of some reflexive pronouns i.e. "themselves" and "ourselves" are used in place of "each other" or "one another"

\subsection{Lexis and Semantics}

Here, some words in the SE have acquired new meanings in Nigeria. New lexical items have also been coined from the existing ones; others are borrowed from other indigenous languages, Pidgin or in translation. Five major categories of lexico-semantic variation in Nigerian English that have been identified by Adegbija (1989) are: transfer, analogy, acronyms, semantic shift or extension and coinages. For reasons of space constraints, a few of these will be examined as follows:

a) Transfer: new meanings foreign to English lexical items are translated directly to English. These include transfer of meaning (bush meat (game), outing, not on seat,), transfer of culture (bride price, introduction, new yam festival, etc), transfer of context (sorry, toast,) transfer of Pidgin features (kola, dash, mammy water). Other examples of transfer are corner (a bend in a road), machine (motorcycle now called okada), mineral (soft drink), escort (to see a guest off) (Adegbija 1989:171, and Alabi, 2003:186-191).

b) Acronyms: are transitional in nature and their use are dictated by the political dispensation that is in power in Nigeria. As culled from Abdullaih-Idiagbon and Olaniyi, (2011) examples include: NADECO (National Democratic Electoral Commission), MAMSER (Mass Mobilization for social and Economic Reliance), NEPA, (National Electric Power Authority), now PHCN (Power Holding Company of Nigeria), NUC (National 
University Commission), and NUJ (Nigerian Union of Journalists).

c) Coinages (or neologisms). These are invented new words and they are categorized into three (Adedimeji, 2007:10): the existing stock in English (half current, yellow fever, bean cake, barb one's hair, go slow); the existing lexical stock in mother tongues (e.g. Agbada, Tuwo, Babanriga, Egunje, Tokunbo,etc); and hybridization of the English and indigenous lexical items (e.g. akara ball, kiakia bus, Tokunbo car, etc.). According to Abdullahi-Idiagbon and Olaniyi (2011), some coinages in Nigerian English have semantic implication in Nigerian socio-political system. Examples of such coinages are: Long -Leg, Free-and Fair, Come-of age, Carpet crossing, no-go-area, Man-of timber and caliber, money bag, political juggernaut/heavyweight, political bride, accord Concordia, bottom power. It is assumed that these coinages are transitional and therefore, cannot be incorporated into the standard Nigerian English lexis.

Some emerging corpora that are obtained through personal observation include: 'how far', a form of greeting that is common among Nigeria undergraduates. It could also mean 'what is the latest development on the last discussion we had' but it is synonymous to 'how are you?' in SE. 'Chairman' is a title used by in-group members for a member who has some attributes that place him above his peers. These attributes have both positive and negative connotations. It is positive when the 'chairman' is more brilliant than his/her mates. The negative connotation is when he is the head of a hoodlum or cult group and is so addressed. 'Big boy' is used to refer to someone who wields influence in terms of connection or is wealthy and can always have his way. The word 'enter' is a synonym of 'board', hence, 'board the taxi' $(\mathrm{SE})$ is 'enter' the taxi in Nigerian English.

All these corpora show that English has indeed been nativized or domesticated and so, Nigerian English do really exists and there are corpora peculiar to either the educated, half-educated, the illiterates and in group language. The resultant variants could be regarded as creative variants resulting from the non-existence of their equivalent terms in English. It is therefore imperative of linguists and sociolinguists to sort out items that are acceptable and those unacceptable in their usage. But cultural exigencies may cause some words, items, expressions to find their way in to the lexicon of Nigerian English, as explained in the preceding sections.

\section{Conclusion}

The linguistic, ethnic, and cultural diversity of Nigeria has no doubt, created complex communication problems. Language variation is a universal phenomenon-when a language leaves its original home to another, it will definitely develop features that are peculiar to the new sociolinguistic environment. Therefore, issues about the evolvement of Nigerian English should be appreciated. The domestication of English language and the pragmatic use of the language to satisfy the needs of communication show that the Nigerian English is one of the world Englishes contributing to the resolution of language and communication problems in the country. However, we want to caution that any discussion of nativization or domestication must not, in any way, jettison social acceptability and intelligibility so that Nigerian English will enjoy a wide and social use. Much as the use of local lexis and idioms allow people to achieve successful intercultural communication, we advocate some measure of restraints. This submission is in line with Jenkins (2000:159) who advocates that only features that are considered vital for the intelligibility of English as an international language should be accepted by linguists and sociolinguists. And believe it is high time efforts were made to standardize and codify Nigerian English and then incorporate it in the dictionary. Igboanusi's effort is commended for his work in producing 'A Dictionary of Nigerian English Usage'. Also, the Macmillan English Dictionary of Advanced Learners: International Students' Edition (2002) has some entries which are traced to West African origin. Such words, which are included in the entries include 'car park' (p.929), 'Mallam' (p. 866). As revealed in the literature, there are many varieties of what we regard as the standard British English, and thus, there are also many new Englishes, which in turn, have sub-varieties. We want to strongly believe that in years to come, all the world's Englishes and native linguistic interactions of other nations of the world are likely to change even more profoundly than it is today, the variety of the English existing in Britain, the traditional home of the language. Thus, Standard English becomes a mere abstract concept which will not in reality exist.

\section{References}

Abdullahi-Idiagbon, M.S.\& Olaniyi, O.K.(2011). Coinages in Nigerian English: A Sociolinguistic Perspective. In African Nebula, Issue 3. Adedimeji, M.A. (2007). The linguistic features of Nigerian English and their implications for $21^{\text {st }}$ century English pedagogy. A paper presented at the $21^{\text {st }}$ Annual Conference of the Nigeria English Studies Association (NESA) themed 'English in the Nigerian Environment: Emerging Patterns and New Challenges held at the CBN Auditorium, University of Uyo, Akwa Ibom State between September $18^{\text {th }}$ and $21^{\text {st }} 2007$. 
Adegbija, E. (1994). "English as an International Language". In Obafemi, O.(Ed.) New Introduction to English Language. Ibadan:YBooks.pp.207-222.

Adegbija, E.(1989). "Lexico-semantic Variation in Nigerian English" World Englishes. (8)2.

Adegbija,E.A.(2004). Language Policy and Planning in Nigeria. ciledrive/dip/2004b, vpsunday,15th2013.

Alabi, V.A. (2003). English Language in Second Language Contexts: The English Language in Nigeria. In O. Obafemi and S. Babatunde (Eds.), Studies and discourse in English language. Ilorin: Haytee Press.

Babatunde, S.T. (2001). The English as a Second Language (ESL) Phenomenon in Nigeria. In S. Babatunde (Ed.), Issues in contemporary English usage. Ilorin: Haytee Press.

Babatunde, S.T. (2002). World Englishes and the paradox of English language teaching in Nigeria. In S. Babatunde and D. Adeyanju (Eds.) Language, meaning and society. Paper in honour of E.E. Adegbija at 50. llorin: Haytee Press.

Bamgbose, A.1995. "English in the Nigerian Environment" In Bamgbose, A. , A. Banjo and A.Thomas (Eds). Ibadan: Mosuru Publisher.

Crystal, D. (1995a). Documenting rhythmical change. In J. Windsor Lewis (ed.). Studies in General and English Phonetics. Essays in honour of Professor J.D. O'Connor. London: Routledge.

Crystal, D. (2003). English as a global language, $2^{\text {nd }}$ edn. Cambridge:Cambridge University Press.

Emenanjo, E.N. (1990). Multilingualism, minority languages and language policy in Nigeria. Agbor: Central Books Ltd.

Hunjo, H.J. (2002). Pragmatics Nativization in New Nigeria English. In S. Babatunde and D. Adeyanju (Eds.). Language, meaning and society. Paper in honour of E.E. Adegbija at 50. Ilorin: Haytee Press.

Igboanuasi, H. (2002). A dictionary of Nigerian English usage. Ibadan: Enicrownfit.

Jenkins, J. (2000). Phonology of English as an International Language. Oxford: Oxford University Press.

Jolayemi, D. (2013). Shifting grounds to widen horizon: Implications for $21^{\text {st }}$ century Researchers and Teachers of English. Being the 1 st lead paper for the $10^{\text {th }}$ annual International Conference of the National Association of Researchers and Teachers of English as a Second Language (NATRESL) Holden at Elizade University, Ilara-Mokin, Ondo State, Nigeria.11 $1^{\text {th }}-14^{\text {th }}$ September 2013

Jowitt, D. (1991). Nigerian English usage. Lagos: Mageh.

Kachru, B.B. (1982). The other tongue: Urbana: University of Illinois Press.

Kachru, B.B. (1992C). Teaching World Englishes. In B.B. Kachru (Eds). The other tongue: English across cultures . Urbana: 2nd ed., Urbana and Chicago: University of Illinois Press.

Kirkpatrick, A, \& Deterding, D. (2011). World Englishes. In James Simpson (Ed.). The Routledge handbook of applied linguistics. New York: Routledge.

Macmillan English dictionary for advanced learners: International students' edition (2002). Malaysia: Macmillan.

McArthur, T. (1998). The English languages: Cambridge: Cambridge University Press.

Federal Republic of Nigeria. (2007). The National Policy on Education.Lagos:NERDC Press.

Odumuh , A.E. (1984). Some Methodological Considerations in the identification and description of Nigerian English. In Freeman R, \& Jubril, M (Eds.). English language studies in Nigerian higher education: London: British Council.

Olatinwo, K.R. (2006). Nativization of English Language and Enhancement of Mass Communication: Nigeria's Experience. In W. Adegbite and B. Olajide (Eds.). English in the Nigerian environment: Emerging patterns and new challenges. Referred Proceedings of the 24th Annual Conference of the Nigerian English Studies Association (NESA). Nigeria: Olivetree Publishing Venture.

Soyinka, W. (1988). Art, Dialogue and Outrage. Ibadan: New Horn Press.

Quirk, R, (1982). International Communication and the Concept of Nuclear English. In Style and Communication in the English language. London: Edward Arnold. 
